\title{
FINANCIAL LIABILITY AND CHILD OFFENDERS IN SOUTH AFRICA
}

\author{
Michelle Karels* \\ LLB LLM LLD \\ Associate Professor, Department of Criminal \\ and Procedural Law \\ University of South Africa (UNISA)
}

\section{SUMMARY}

This submission is a theoretical examination of pecuniary liability in the case of child offenders in terms of the Child Justice Act 75 of 2008. It considers the financial position of child offenders in the ordinary course of criminal action viz. the obligation to pay bail, fine(s) or compensation orders, etc. Thereafter the potential latent financial liability of parents arising from the criminal actions of their offspring will be considered. The financial and legal accountability of parents will be considered and compared with the position of South African parents as opposed to that of parents in England and Wales. Finally, the submission queries, the practical operation and implementation of contribution orders in terms of the Children's Act 38 of 2005. A comparison of the use of such orders with the practice in the United States of America follows. The submission postulates that contribution orders are merely one example of potential financial liability for criminal conduct within the Child Justice Act 75 of 2008, which may materially affect the parent(s), guardian, or appropriate adult responsible for the care of a child offender.

\section{INTRODUCTION}

Civilized society, in doing away with private vengeance, assumed that the State would take effective control of criminal prosecution and crime control. ${ }^{1}$ Resultantly, state systems of criminal justice, as a representative of society, assume the position of the victim as a collective. The mechanisms of criminal justice are, however, an expensive pursuit. When states assumed control of their respective criminal-justice systems, they did so on the understanding that the cost of investigation, prosecution, correctional care and rehabilitation would be for the account of state coffers. ${ }^{2}$ Resultantly, in contemporary societies, any criminal action instituted by the State against a person accused of transgressing the criminal law is funded by the State. The only financial responsibility on the part of the accused is the cost of private legal representation, payment of bail, possible fines and compensation or

\footnotetext{
The author extends her gratitude to the Research Department of the University of South Africa for funding research undertaken at the University of Utrecht. The views herein expressed, however, represent those of the author.

Joubert et al Criminal Procedure Handbook 11ed (2014) 50.

Joubert et al confirm that criminal prosecution is "state-funded" 55 .
} 
restitution ${ }^{3}$ orders. ${ }^{4}$ For an adult accused, financial obligations arising from criminal action are disposed of in a variety of ways, such as making the accused discharge these financial obligations with funds earned by employment or other sources of income. ${ }^{5}$ In the case of child offenders, the financial implications of criminal prosecution are not as clear-cut. A child offender is financially responsible on a similar basis as an adult accused for private legal representation, bail, ${ }^{6}$ fines, ${ }^{7}$ and compensation or restitution orders, ${ }^{8}$ but the mechanism of satisfying these obligations is not as obvious as is the case with adult accused. Inevitably, the cost is borne by parent(s), guardians or appropriate adults of the child. ${ }^{9}$ Parental satisfaction of financial liability on behalf of a child offender, leads to two avenues of inquiry in the South African system of child justice, viz. the responsibility, albeit financially, of parents for the criminal misdeeds of their offspring; and the potential use of contribution orders against parents for the costs associated with the criminal prosecution of a child offender. These avenues will be considered against the recent revolt against punitive court charges in the United Kingdom, which make it clear that the days of exclusively state-funded criminal prosecution may be numbered. ${ }^{10}$

\section{THE CHILD JUSTICE ACT 75 OF 2008}

The Child Justice Act 75 of $2008^{11}$ adopts a pragmatic approach to the challenge of childhood criminality in South Africa. Quintessentially, it places a child offender in a position of accountability, either through formal criminal trial process or the implementation of diversion processes. After the preliminary inquiry, ${ }^{12}$ a child offender, called to account in a child justice

3 In terms of $\mathrm{S} 300$ and 301 of the Criminal Procedure Act 51 of 1977 (hereinafter "the Criminal Procedure Act").

4 These are direct costs within the process of criminal prosecution and do not take into account the personal cost to the accused, such as lost income, etcetera. It is trite that such costs have long been considered the ordinary consequence of criminal conduct and as such are not unconstitutional or generally unfair.

5 In some cases, such costs are borne by spouses, family members and friends. The monetary input by such persons is not beyond the bounds of reasonableness. The payment of such sums by $3^{\text {rd }}$ parties on behalf of the accused is a matter of choice and there is no obligation on such parties to fund an accused.

6 Except that in the case of child offenders a bail amount may not be set which the child and his parents cannot afford - s 25(1)(c) of the Child Justice Act.

7 Except that fines cannot be set where the child or his parents cannot afford to comply if the alternative is imprisonment $-s$ 74(1) of the Child Justice Act.

8 In terms of s 300 and 301 of the Criminal Procedure Act and s 53(3) and (4) of the Child Justice Act 75 of 2008.

9 For the sake of brevity, the word "parent" is used hereinafter to include guardians and appropriate adults.

10 Criminal court charges ranging between $£ 150$ and $£ 1200$ came into effect in April 2015. The notion according to Bowcott "Magistrates resign" The Guardian, "It is right that convicted adult offenders who use our criminal courts should pay towards the cost of running them". http://www.theguardian.com/law/2015/jul/31/magistrates-resign-court-charges-encourageinnocent-plead-guilty (accessed 2015-08-17).

11 Hereinafter "the Child Justice Act".

12 With the exception of diversion ordered in terms of $s 41$ and 42 of the Act. 
court, undergoes an ordinary criminal trial, ${ }^{13}$ with the exception of a childjustice-specific features, such as mandatory legal representation. If the court of preliminary inquiry or child justice decides that diversion is an appropriate option it will order diversion under the conditions prescribed by the Act. ${ }^{14}$

Although the Act is premised on restoration of relationships between the offender, the victim and society and the best interest of the child, it cannot totally do away with certain formal ${ }^{15}$ and informal ${ }^{16}$ financial implications for the account of the child offender. These costs arise during the pre-trial, trial and post-trial process. These potential financial obligations are set out below.

\section{Pre-trial financial implications}

At the pre-trial stage, actual, formal costs include potential bail payments made by the child offender or on his behalf. The bail hearing remains subject to Chapter 9 of the Criminal Procedure Act, read with section 25 of the Child Justice Act. When a bail court considers bail, it must conduct an independent inquiry into the ability of the child or parents to pay bail. If the court finds that neither the child nor parents can afford bail, bail must be granted subject to conditions other than the payment of money. ${ }^{1}$

Another example of formal pre-trial cost, which may arise independently to bail, relates to diversion ordered in terms of section 41 and 42 of the Act. In these cases, the prosecutor may divert the matter prior to the preliminary inquiry when the offence in question relates to schedule 1 of the Act. ${ }^{18}$ The diversion options applicable include the "payment of compensation to a specified person, persons, group of persons or community, charity or welfare organisation or institution where the child or his or her family is able to afford this ..."19 There is no obligation to conduct an assessment of the child's ability to pay compensation ${ }^{20}$ but section $55(1)$ (c) prevents the imposition of a diversion option which "completely excludes certain children due to a lack of resources, financial or otherwise; ..."

At the preliminary inquiry, diversion may be ordered for any schedule of offence $^{21}$ and may include payment of compensation by the child offender or his parents ${ }^{22}$ or, in the case of a level-two diversion option, ${ }^{23}$ compulsory

13 See $s 63(1)(b)$ of the Act: A child-justice court must apply the relevant provisions of the Criminal Procedure Act relating to plea and trial of accused persons, as extended or amended by the provisions as set out in this Chapter and Chapter 10.

14 S 59 of the Act.

15 By "formal", the author means costs that are attached to an order of court or other compulsory cost in the child-justice process.

16 By "informal", the researcher means costs not attached to a formal consequence for nonpayment. The informal costs are discussed separately because they occur throughout the trial process.

17 S 25(2)(c)(i) of the Child Justice Act.

18 S 41(1) of the Child Justice Act.

$\mathrm{S} 53(3)(\mathrm{p})$ of the Child Justice Act.

At least not in terms of $s 41$ and 42 of the Child Justice Act.

$S 49(1)(a)$, read with the specific provisions of Chapter 8 of the Child Justice Act.

$\mathrm{S} 53(3)(\mathrm{p})$.

Applicable to schedule 2 and 3 offences in the Child Justice Act. 
attendance of a vocational, educational or therapeutic programme, ${ }^{24}$ or referral for intensive therapy or treatment. ${ }^{25}$ Any of the level-two options can include a temporary residence order. ${ }^{26}$ Once again, there is no obligation to conduct an assessment of the child's ability to pay compensation, ${ }^{27}$ but section 55(1)(c) prevents the imposition of a diversion option which "completely excludes certain children due to a lack of resources, financial or otherwise; ..."

\section{Financial implications arising during trial}

A child offender cannot appear in a child justice court unrepresented. ${ }^{28}$ While the cost of legal representation ${ }^{29}$ is carried by the State in certain circumstances, ${ }^{30}$ the child retains the constitutional right to choose and consult with legal representation of choice where the child's circumstances financially permit. $^{31}$ In general circumstances the cost of private legal representation is for the account of the child, the child's parents or family members where the child does not make use of Legal Aid South Africa.

A child justice court, like the court of preliminary inquiry, can order diversion for any schedule of offence. ${ }^{32}$ The diversion options available include all of those contained in section 53 of the Child Justice Act, with emphasis on those detailed at paragraph 21 above.

\section{Financial implications arising from sentencing}

Costing the sentencing of a child offender ordinarily relates to sentences involving fines. Sentencing can, however, include monetary responsibilities associated with any of the options included in section $53^{34}$ of the Act, which may be imposed as part of a sentence. ${ }^{35}$ Financial liability may further arise from restorative justice sentences $^{36}$ that involve the payment of compensation or restitution ${ }^{37}$ by the child offender or family. ${ }^{38}$

\footnotetext{
S 53(4)(b) of the Child Justice Act.

S 53(4)(c) of the Child Justice Act.

The issue of residence becomes central to the authors argument later in this submission.

At least not in terms of $s 41$ and 42 of the Child Justice Act.

The court cannot receive a plea from an unrepresented child offender $-\mathrm{s} 83$ of the Child Justice Act.

29 Nothing precludes the representation of a child in the pre-trial stage (s 81 of the Child Justice Act) but it is mandatory at the trial stage and is thus discussed here. The researcher's cost-based argument applies to the cost of legal representation at the pre-trial phase.

$\mathrm{S} 82$ of the Child Justice Act.

$31 \mathrm{~S} 35(3)(\mathrm{f})$ of the Constitution of the Republic of South Africa, 1996 (hereinafter "the Constitution").

$32 \mathrm{~S} 67$ of the Child Justice Act.

33 Those options involving costs for the child and/or parent.

34 In the framework of this submission, the author concentrates on payment of compensation.

35 S 72(1) of the Child Justice Act.

36 Restorative justice sentences usually include family group conferencing or victim-offender mediation.

37 In terms of the Child Justice Act or Criminal Procedure Act.

$38 \mathrm{~S} 73$ read with s 61 and 62 of the Child Justice Act.
} 
The imposition of a fine is the more traditional financial implication associated with sentencing a child offender. A fine may be imposed on a child offender, ${ }^{39}$ if the court has considered the financial ability of the child and parents to pay the fine. ${ }^{40}$ Where the court finds that the child or parents cannot pay the fine it may order symbolic restitution, compensation, the provision of a service by the child or any other option it considers suitable, in lieu of a monetary fine. ${ }^{41}$

\section{Post-trial financial implications}

Post-trial costs for a child offender or parents relate to appeal and review procedures where private legal counsel is retained. ${ }^{42}$ In addition, section 86 of the Act creates the possibility of bail, and thus monetary liability, in the case of appeal and review proceedings where the services of Legal Aid South Africa or NGO's are not retained.

The above represent formal financial implications associated with the criminal prosecution of a child offender. The above do not include potential non-formal costs, which are discussed below.

\section{Informal financial implications associated with the pre-trial, trial and post-trial process}

The formal financial liabilities associated with an accusation of criminal conduct are not the only monetary implications for the accused in the ordinary course of events. Additional costs, such as transport, lost income and missed schooling, affect child offenders in the same degree as adult offenders. The difference, however, is that often these incidental financial costs impact on the parents and family of the child offender. The financial costs are extended because the parent loses time, income and/or potential income because they are usually the conduit between, for example, the child's appearance at trial ${ }^{43}$ or appearance at diversion programmes that are non-residential.

It is trite that the costs, both formal and informal, resulting from the criminal process, are an ordinary and accepted consequence of being accused of a crime. Supposedly, the protections offered as part of fair trial rights prevent these financial costs from being considered punitive. Financial responsibility, however, can be considered sui generis in the case of child offenders, since logically the parents and other caregivers are accountable for the child's monetary responsibility. While the Act has attempted to move away from monetary release on bail and punishment, unless the child or family can afford it, the question remains how parents, directly or indirectly, can be held responsible for the financial costs associated with criminal

\footnotetext{
S 74(1) of the Child Justice Act.

S 74(1)(a) of the Child Justice Act.

S 74(2)(a)-(d) of the Child Justice Act.

42 See s 84 and 85 of the Child Justice Act for the appeal and review procedures relating to child offenders.

43 See $\mathrm{s} 65$ of the Child Justice Act relating to parental assistance at trial.
} 
action against their children. ${ }^{44}$ In the ordinary course of events, third parties have a choice whether to support an adult accused financially. In the case of a child offender, the decision to financially support or abandon must, however, be viewed against the co-dependency of a child on its parents. In extension, to what degree may a parent in the South African justice system be held to account to a court for the criminal behaviour of a child offender? Although it is trite that parents cannot be held criminally liable for the actions of their children, unless they were involved in the crime, or used the child to commit a crime, it is clear that they take some responsibility, albeit financially, for the criminal actions of their children. The situation pertaining to one of these inquiries is explored below with reference to England and Wales.

\section{CRIMINAL RESPONSIBILITY AND PARENTAL ACCOUNTABILITY IN ENGLAND AND WALES}

A unique aspect of the English system of child justice is the ability of the court to bind-over parents. "Binding-over" effectively means that the parents suffer consequences for their children's criminal action. The consequence can take the form of a fine or an order to attend parenting classes, or other forms of social assistance, against the parent.

A parent cannot be held criminally accountable for the actions of his child per se, but can be bound-over by the court, because of the actions of the child. Where, for example, the court orders the parent to attend parenting courses or to pay a fine on behalf of the child, the parent is effectively accountable on account of that order. Section 8 of the Crime and Disorder Act of 1998 , for example, allowed the court to make parenting orders for a maximum of 12 months, which ordered a parent or guardian to attend parenting classes or social-assistance programmes.

The 1991 Youth Court (Criminal Justice Act) ${ }^{45}$ introduced the concept of bind-overs, ${ }^{46}$ which allowed the courts to fine a parent up to a maximum of $£ 1000$ for failure to exercise proper care over a child who offended or reoffended.

The 1993 murder of Jamie Bulger ${ }^{47}$ fundamentally altered the outlook of juvenile justice in England and Wales. ${ }^{48}$ This resulted in various

44 In private law the costs of a child's actions are governed by well-established principles. In the case of criminal actions by a child the area of law is not well developed.

45 Dignan "England and Wales" in Dunkel, Grzywa, Horsfield and Pruin (eds) Juvenile Justice Systems in Europe Vol 1 (2010) 357-398 360.

46 Gelsthorpe and Fenwick "Comparative Juvenile Justice: England and Wales" 1997 Juvenile Justice Systems: International Perspectives 77-112. See also, Drakeford "Parents of Young People in Trouble" 1996 Howard Journal of Criminal Justice 242-255.

47 Scott "Death of James Bulger" Crime Library http://trutv.com/library/crime/notorious/ murders/young/bulger/1.html (accessed 2013-03-13). See also Graham and Moore "Beyond Welfare Versus Justice: Juvenile Justice in England and Wales" International Handbook of Juvenile Justice (2008) 65.

48 Graham "Juvenile Crime and Justice in England and Wales" in Bala, Hornick, Snyder and Paetsch (eds) Juvenile Justice Systems: An International Comparison of Problems and Solutions (2002) 67-106 85, comments that the death of James Bulger was the final straw in a period of time which saw a dramatic rise in crime committed by young offenders; Levine 
amendments to legislation, which saw an increasingly punitive attitude towards child offenders between the ages of 12 and 15 years. The result of an increased focus on the punitive approach was the enactment of the 1994 Criminal Justice and Public Order Act, ${ }^{49}$ which extended the possibility of imprisonment as a sentence for children between the ages of 10 and 13 years. ${ }^{50}$ The same Act extended the maximum length of time to which a court could confine a child in young-offender institutions from 12 to 24 months. The Act retained the court's power to bind-over parents in order to ensure their compliance with any community-based sentence. ${ }^{51}$ When ordering a bind-over the court can order the payment of the fine by the parents. $^{52}$ By contrast, a bind-over order directed at the juvenile is an order in terms of which the offender is ordered to conduct himself in an orderly fashion for a specified period. In recognition of intention, the court holds an amount of between $£ 250$ and $£ 1000$ as a form of security, which is given back to the child after successful completion of the sentence period.

Section 150 of the Powers of the Criminal Courts (Sentencing) Act 2000 stipulates that on sentencing a young offender the court may bind-over a parent or guardian. Practically the court, on conviction, "with the consent of the offender's parent or guardian, ... order[s] the parent or guardian into a recognizance to take proper care of him and exercise proper control over him ....54 If a parent or guardian refuses, and the court considers the refusal unreasonable, the parent or guardian can be ordered to pay a fine not exceeding $£ 1000^{55}$ The fine is deemed to "be a sum adjudged to be paid by a conviction ...,56 In the Crown Court a refusal to be bound-over is

"Rethinking Bystander Non-intervention: Social Categorization and the Evidence of Witnesses at the James Bulger Murder Trial" 1999 Human Relations 1133-1155; James and Jenks "Public perceptions of Childhood Criminality" 1996 British Journal of Sociology 315-331; Smith The Sleep of Reason: The James Bulger Case (2011).

49 Graham and Moore International Handbook of Juvenile Justice 65.

50 Ibid.

51 Graham Juvenile Justice Systems: An International Comparison of Problems and Solutions 85.

52 Wakefield and Hirschel "England" in Schoemaker International Handbook on Juvenile Justice (1996) 90-107 102.

53 Ibid.

$54 \mathrm{~S} 150(2)(\mathrm{a})$ of the Powers of the Criminal Courts (Sentencing) Act 2000.

55 150(2)(b) of the Powers of the Criminal Courts (Sentencing) Act 2000

56 S 150(6) of the Powers of the Criminal Courts (Sentencing) Act 2000. According to the Crown Prosecution Service http://www.cps.gov.uk/legal/a to c/binding over orders/ (accessed 2015-10-22), the practice and procedure in relation to binding-over is now regulated by the Criminal Practice Direction [2013] EWCA Crim 1631, which came into force on 7 October 2013. This direction takes into account the judgments of the European Court of Human Rights in Steel $v$ United Kingdom (1998) Crim LR 893 and in Hashman and Harrup v United Kingdom (2000) Crim LR 185. The Direction applies to orders made under the courts' common-law powers and all those conferred by Statute in both the magistrates and Crown Courts.

The key points are:

- The court must be satisfied that a breach of the peace involving violence, or an imminent threat of violence has occurred, or that there is a real risk of violence in the future. Such violence may be perpetrated either by the offender or a third party as a result of the offender's conduct.

- Rather than binding-over to "keep the peace" in general terms the court should identify the specific conduct or activity from which the individual must refrain. 
considered contempt of court because there is no specific procedure provided therefore as is the case in the magistrates court.

The position in English criminal procedure appears to hold a parent both financially responsible and criminally liable in certain instance, for the conduct of a child offender. The criminal responsibility of a parent arises when the bind-over order is breached. The financial responsibility results from the courts ability to order payment of, for instance, fines by the parent on behalf of the child.

An alternative to bind-over orders is the use, as demonstrated in the United States of America, of contribution orders under the juvenile delinquency system.

\section{CONTRIBUTION ORDERS IN TERMS OF THE AMERICAN CHILD-JUSTICE SYSTEM}

The position of a parent in the American system of juvenile justice provides an example of the use of contribution orders, which some commentators view as a form of accountability on the part of a parent for the criminal actions of their child. The American system is an example of the recent use of parental-accountability actions and sanctions applied by the court on parents as a result of their child's delinquent behaviour. ${ }^{58}$

Pennington ${ }^{59}$ submits that the function of the parent has changed over the historical-development period of the system itself. Initially they were viewed as the cause of delinquency in their children. After the decision in Gault, ${ }^{60}$ the focus shifted to the individual rights of the child and excluded the family

- The conduct or activities should be written down and served on all relevant parties. Reasons should be given. The length of the order should be proportionate to the harm and generally not exceed 12 months.

- Representations should be heard from the offender and the prosecution about the making of the order and its terms.

- If disputed, the parties may call evidence (if not already heard in the proceedings).

- Even if there are admissions and consent, the court should still hear representations and, if appropriate evidence, to satisfy itself to making the order and to clarify its terms.

- The burden of proof is beyond reasonable doubt.

- The court should announce it is satisfied that an order be made before considering the recognizance sum, and then invite representations.

- The offender's means must be taken into account when considering the amount of the recognizance.

- Alternatives to a bind-over should be considered if there is a possibility of a refusal to be bound-over.

- Opportunity to see a duty solicitor or be otherwise represented should be afforded before committal to custody.

- If representation is declined there should be offered a final opportunity to comply and the consequences of the failure explained.

57 Http://www.cps.gov.uk/legal/a_to_c/binding_over_orders/ (accessed 2015-10-22).

58 Pennington "Engaging Parents as a Legitimacy Building Approach in Juvenile Delinquency" 2012 University of California Davis Journal of Juvenile Law and Policy 490.

59 Pennington 2012 University of California Davis Journal of Juvenile Law and Policy 503.

60 In re Gault, 387 U.S. 1, 87 S.Ct. 1428, 18 L. 2 ed 527 (196). The court in this matter decided that the juvenile-delinquency system must provide due process and legal representation to children accused of a crime. 
unit as a party to the court process. ${ }^{61}$ The contemporary view of the parent as a party in the child-justice process is contextualized within the social demand for justice and policy that effectively controls delinquent action. ${ }^{62}$ Within the early view of parents as cause of delinquency, their interaction with the juvenile-justice process was little more than as being the recipients of the judges scorn and lecturing as to their moral blameworthiness. The post-Gault era recognized that parents had the right to be informed of the process against the child, but focused mainly on the rights of the child. The court did not clarify the position of the parent within the child-justice process. $^{63}$

The contemporary view of the parent in the juvenile process occurs within the context of increasing levels of juvenile delinquency, and the role of the media in demanding justice, even when based on sensationalist cases exclusively. Parents, in the current process, have returned to being agents of blame. Resultantly, they are often punished along with the child in an increasingly punitive child-justice process in the United States of America. ${ }^{64}$ California, New York and Illinois, for example, require parents to financially contribute towards the institutionalization of their delinquent child in certain instances. At least 17 states have passed legislation that holds parents accountable for the delinquent acts of their children. ${ }^{65}$ In most state systems of juvenile justice, the parent is expected to be part of the adjudication and rehabilitation process of their delinquent child ${ }^{66}$ In some states, the parent is cited as a respondent to the petition. ${ }^{67}$ There are a variety of statutes that permit a court to impose fines or restitution orders on parents, but the author's interest here is the issue of contribution to the cost of care as part of disposition. ${ }^{68}$ In Colorado, for example, $\$ 19-1-115$ of the CRS Ann, ${ }^{69}$ authorizes a court to make contribution orders against parents to contribute to the cost of placing a juvenile delinquent with a public-service agency or Department of Human Services. \$19-2-114 permits the court to order contribution to costs when a child is placed outside of the family home after adjudication as a juvenile delinquent.

As Foster and Mundt ${ }^{70}$ summarise the situation:

"the parents of a delinquent juvenile can expect to pay more than just attorney fees and court costs associated with the adjudication of a juvenile. Parents whose child is placed in a residential facility or foster care also must contribute to the cost of care ..."

\footnotetext{
Pennington 2012 University of California Davis Journal of Juvenile Law and Policy 503. Ibid.

Pennington 2012 University of California Davis Journal of Juvenile Law and Policy 511. Ibid.

Foster and Mundt "Parental Financial Liability for Juvenile Delinquents" 2008 Juvenile Law $49-55$.

66 In most states, the juvenile delinquency system is run through the family-court system. In some states, there are waiver/transfer statutes that permit the transfer of a juvenile delinquent to the adult criminal-trial system.

67 Foster and Mundt 2008 Juvenile Law 49-55.

68 Disposition in the American system is the equivalent of sentencing in South Africa.

69 Colorado Revises Statutes.

70 Foster and Mundt 2008 Juvenile Law 49-55.
} 
From the brief comparative analysis above, it is clear that some jurisdictions require and can order a parent to be accountable for its child's financial obligations. In others, the court can impute direct responsibility to parents and, in some cases, can order a parent to contribute to the cost of criminal action against, and/or rehabilitation of, its delinquent child.

The position in South Africa is distinct from the position in both England and the United States of America. While it is clear that a parent cannot be directly fined, or ordered to pay compensation in South Africa, the mere fact that the Child Justice Act requires a court to consider the financial position of parents in certain instances, is indicative of the fact that parental financial support is an expected norm. The legal position regarding a contribution in South Africa is, however, unclear. The basis for the use of contribution orders is contained in Chapter 10 of the Children's Act 38 of 2005. ${ }^{71}$

\section{CONTRIBUTION ORDERS: CHAPTER 10 OF THE CHILDREN'S ACT 38 OF 2005}

A children's court may order a respondent to contribute, either recurrently or temporarily, towards the maintenance or treatment of a child placed in alternative care, or to costs, where a child is removed from the family for treatment, rehabilitation, counselling or other reason. ${ }^{72}$ The order has the effect of a maintenance order and is governed under the Maintenance Act and the Reciprocal Enforcement of Maintenance Orders Act, 80 of $1963 .^{73}$ Alternative care is defined to include a child placed in a child and youth care centre in terms of the Children's Act or under section $29^{74}$ or Chapter $10^{75}$ of the Child Justice Act. ${ }^{76}$

The Children's Act centres on the welfare needs of a child, but interfaces with the Child Justice Act for a variety of reasons aimed at protecting the best interest of a child. The criminal conduct of a child, however, has a variety of challenges connected to accountability for action, whereas welfare needs are often primarily based on the actions of others that affect a child.

It is clear that the Children's Act permits the imposition of contribution orders where a child is placed in alternative care, or is otherwise in need of maintenance or assistance. It is further clear that the Children's Act envisages that child offenders, under section 29 and Chapter 10 of the Child Justice Act, qualify under the definition of "alternative care" for purposes of contribution orders. What is unclear, however, is how these two legislative instruments interface, and to what degree, if any, a child justice court has the power to order a parent to pay contribution to the maintenance of a child

\footnotetext{
Hereinafter "the Children's Act".

S 161(1)(a) and (b) of the Children's Act.

S 163(1) of the Children's Act.

74 Placement in a child and youth-care centre prior to sentencing. This section relates to placement before or after the preliminary inquiry, dependant on the schedule of offence in question.

75 Chapter 10 deals with sentencing of child offenders. It includes the option of placement in a child- and youth-care centre.

76 S 167(1)(b) of the Children's Act.
} 
placed in alternative care pending trial, ${ }^{77}$ or as a result of being found guilty of an infringement of a criminal law. ${ }^{78}$ The position is unclear partly due to the jurisdictional restrictions placed on courts under both Acts, the presumption of innocence guaranteed by the Constitution and the nature of compensation orders in South Africa.

\section{Children in need of "care and protection" and contribution in the case of criminal sanction}

Where a preliminary-inquiry court, or child justice court, determines that a child offender is a child in need of care and protection, does not live in a family home, or has committed a minor offence to satisfy basic human needs such as food or warmth, it may refer the child offender to a children's court to be dealt with by that court. ${ }^{79}$ Once the child is transferred to the children's court under the auspices of the care and protection provisions of the Children's Act, the child is dealt with in terms of the provisions of that Act.

Any child offender that does not fall into the categories mentioned above proceeds through the justice process according to the provisions of the Child Justice Act. While this situation is logical - in that it allows the child justice courts to protect vulnerable children - it limits a preliminary inquiry and childjustice court's ability to make a contribution order, and/or parenting order, as envisaged under the Children's Act in the case of the ordinary criminal process where the child is not vulnerable or in need of care and protection. The court of preliminary inquiry or child justice only has the potential to make a contribution order as part of remand placement or sentencing, but not in the case of diversion.

It is submitted that the situation may be prima facie resolved by adopting the position of the Children's Act's whereby every magistrates court can sit as a children's court, but does not warrant the presumption that a child justice court can sit as both a children's court and child justice court in the same instance. ${ }^{80}$ Clearly, the Children's Act envisaged the use of contribution orders in child justice proceedings as part of placement on remand, or as part of sentencing. There are, however, challenges that arise from the interface between the Children's Act and Child Justice Act in this regard.

\footnotetext{
S 29 of the Child Justice Act.

Chapter 10 of the Child Justice Act.

S 50 of the Child Justice Act.

80 A children's court in terms of s 42(1) of the Children's Act is constituted as "every magistrate's court, as defined in the Magistrates' Courts Act, 1944 (Act 32 of 1944), shall be a children's court and shall have jurisdiction on any matter arising from the application of this Act for the area of its jurisdiction". By contrast a child justice court is defined in $s 1$ of the Child Justice Act as "any court provided for in the Criminal Procedure Act, dealing with the bail application, plea, trial or sentencing of a child".
} 


\section{Placement on remand and the presumption of innocence}

Section 29 of the Child Justice Act regulates placement in a child and youth care centre prior to sentencing. It mandates the factors that a court must deliberate in considering such placement. ${ }^{81}$ This is one of the situations, which the Children's Act identifies as suitable for the imposition of a contribution order, presumably against the parents or other party responsible for the child offender. It is submitted that contribution in this sense raises concerns over the right to be presumed innocent which are not sufficiently addressed in Chapter 10 of the Children's Act. If a child justice court orders such contribution before conviction, it is effectively burdening the parents of a child offender who is presumed innocent. If the order takes place after conviction, but before sentencing, questions may be raised concerning the financial responsibility of parents towards financial costs traditionally for the account of the State. If, for instance, the court orders contribution the question arises whether the parents have any say over where the child is placed and the conditions of such detention, especially in light of the specific provisions of section 29 of the Child Justice Act.

The Children's Act further stipulates that contribution orders can be made in terms of Chapter 10 of the Child Justice Act where a child is sentenced to a child and youth care centre, or to a process of treatment, rehabilitation or counselling.

\section{Contribution orders and sentence to child and youth care centres}

Chapter 10 of the Child Justice Act permits a child justice court to sentence a child offender to a child and youth care centre in terms of section 76 ,

29. Placement in a child and youth care centre.

(1) A presiding officer may order the detention of a child who is alleged to have committed any offence in a specified child and youth care centre.

(2) When a presiding officer must decide whether to place a child in a child and youth care centre referred to in subsection (1), consideration must be given to the following factors:

(a) The age and maturity of the child;

(b) the seriousness of the offence in question;

(c) the risk that the child may be a danger to himself, herself or to any other person or child in the child and youth care centre;

(d) the appropriateness of the level of security of the child and youth care centre when regard is had to the seriousness of the offence allegedly committed by the child; and

(e) the availability of accommodation in an appropriate child and youth care centre.

(3) Whenever a presiding officer is required to make a decision in terms of subsection (1), the presiding officer must consider the information referred to in section 40(2).

(4) Where the information referred to in subsection (3) is, for any reason, not available, called into question or no longer current, the presiding officer may request the functionary responsible for the management of a child and youth care centre to furnish a prescribed sworn statement in respect of -

(a) the availability or otherwise of accommodation for the child in question; and

(b) all other available information relating to the level of security, amenities and features of the centre. 
where the child requires a programme as defined in section $191(2)(\mathrm{j})^{82}$ of the Children's Act. In this case, the jurisdiction of the children's court is required to make a contribution order in terms of section 161(1) of the Children's Act. In these cases, however, the child offender has not been referred to a children's court, but has instead been sentenced by a child justice court. Neither the Children's Act, nor the Child Justice Act sufficiently addresses the issue of jurisdiction concerning contribution in the case of sentencing to a child and youth care centre. In addition, neither Act specifically provides criteria on which such an order can be made nor for how long it may be imposed. The use of contribution orders in this fashion further raises concern over who is responsible for the cost of the post-trial rehabilitation of child offenders; parents or the State. The use further opens a line of inquiry into the responsibility of a parent for the criminal actions of its child. In the alternative, contribution used in this fashion may expose indigent families to imprisonment where the parent cannot afford contribution, especially in light of the fact that neither the Children's Act nor the Child Justice Act addresses this issue sufficiently.

It is submitted that contribution orders should not play a role in neither section 29 nor Chapter 10 of the Child Justice Act. It is recommended that contribution orders may have some role to play in diversion proceedings as alternatives to a formal, state-sponsored, criminal trial.

\section{Contribution to diversion programmes}

It is submitted that diversion is an alternative to criminal trial and thus does not fall within the definition of a state-sponsored mechanism of justice. Seen in this light, it is submitted that any court making a diversion order under Chapter 8 of the Child Justice Act should have jurisdiction to order contribution to the cost of the diversion. The legislative authority for such an order should, it is argued, lie within the Child Justice Act and not the Children's Act. Naturally, indigent families should be protected in a similar fashion to section 55(1)(c) of the Child Justice Act. The legitimacy of contribution orders should be supported by clear guidelines regarding the consideration of, and extent of contribution in the case of diversion.

\section{CONCLUSION}

The Child Justice Act does not impute financial responsibility on child offenders short of those normally associated with the criminal justice process. Financial responsibility comes into play within the child justice process in terms of bail, compensation and restitution under sections 300 and 301 of the Criminal Procedure or the Child Justice Act, and in the

82 191(2) A child- and youth-care centre must offer a therapeutic programme designed for the residential care of children outside the family environment, which may include a programme designed for -

(j) the reception, development and secure care of children in terms of an order -

(i) under s 29 or Chapter 10 of the Child Justice Act, 2008;

(ii) in terms of $S 156$ (1) (i) placing the child in a child- and youth-care centre which provides a secure care programme; or

(iii) in terms of $\mathrm{s} 171$ transferring a child in alternative care. 
imposition of a fine as a form of sentence. The Child Justice Act is, however, specific that bail, and the payment of a monetary fine, must be considered within the means of a child offender and parents. Where there is a risk that a child offender may be detained, pending the criminal process, or face imprisonment when a fine cannot be met, courts are required to consider alternatives. The formal criminal processes that involve and exchange of money for liberty are thus restricted, and controlled by the Act.

Diversion orders centre on the Act's restorative paradigm, and require courts to consider therapeutic measures as part of their child-justice jurisprudence. The measures provided for in the Act, as a public-law instrument of criminal justice, are state-funded. It is trite that South African criminal justice has long operated as a state-sponsored system in which the accused is required to fund very little, short of private legal representation, bail payments, compensation and restitution, and, potentially, monetary fines. Diversion, as part of the Child Justice Act permits restitution, either symbolically or in monetary form, as part of accountability. Logically, most monetary responsibility of child offenders falls to parents, guardians or appropriate adults. Although this situation does not impute criminal responsibility on parents, it opens a line of inquiry into the nature and scope of parental responsibility for the criminal action of their children. Where the child offender is considered for diversion the court can consider alternatives to compensation and restitution, where such is not within the reach of the family or child. The Child Justice Act is regulated through provisions which do not permit a child's best interests to be undermined by a lack of financial resources. This position, however, raises the following two questions: firstly, can the Act be equally applied where a child offender from a financially comfortable family has the option to pay for liberty, punishment, compensation, restitution and/or the conditions of diversion; and secondly, to what degree do parents, who can afford these measures, be accountable for the criminal misdeeds of their children?

The implications of section 300 and 301 of the Criminal Procedure Act are unrestricted when employed in a matter involving a child offender. ${ }^{83}$ The compensation/restitution sections of the Criminal Procedure Act are applicable, where the formal requirements are satisfied, when a child has been found guilty by a child justice court and, logically the payment in terms of such an order would be that of the parents. Compensation and restitution within the framework of the Child Justice Act have an extended meaning within the diversion process. In terms of section 53(3)(I),(m) and $(p)$ of the Child Justice Act the court, as part of a diversion order, can require symbolic restitution, restitution, and/or payment of compensation "where the child or his or her family are able to afford this". ${ }^{84}$

In essence, a child offender may receive bail or a punishment attached to a condition other than the payment of a sum of money, where the child or family cannot afford to contribute to these mechanisms of liberty. Where the situation relates to compensation or restitution under the Criminal Procedure

\footnotetext{
Schedule 5 of the Child Justice Act.

${ }^{84}$ S 53(3)(p) of the Child Justice Act.
} 
Act there are no alternatives built into that Act where the child or family cannot afford to comply.

The issue of contribution by parents to the cost of alternative care for their children is not sufficiently resolved by the Children's Act. As it currently stands, the provisions for contribution orders taken from the Children's Act make for a procedurally sui generis situation that is untenable in light of the various factors identified by the author. It is concluded that contribution orders may be better deployed in the case of diversion proceedings as opposed to the pre-trial remand or sentencing of a child offender, which are based on the action, and financial responsibility of the State. 